\title{
THE EVALUATION OF THE EFFECTS OF N-ACETYLCYSTEINE ON CISPLATIN-INDUCED ALTERATIONS IN EXPLORATORY ACTIVITY IN ELEVATED PLUS MAZE TEST IN RATS
}

Milica Pantic ${ }^{10}$ and Milos Minic ${ }^{2 *}$

${ }^{1}$ Department of Physiology, Faculty of Medical Sciences, University of Kragujevac, Kragujevac, Serbia

${ }^{2}$ Department of Anatomy, Faculty of Medical Sciences, University of Kragujevac, Kragujevac, Serbia

"Milica Pantic and Milos Minic contributed equally (50\% each) to this work, and both should be considered first authors

\author{
ISPITIVANJE EFEKATA N-ACETILCISTEINA NA PROMENE \\ EKSPLORATIVNE AKTIVNOSTI U TESTU UZDIGNUTOG KRSTASTOG \\ LAVIRINTA IZAZVANE CISPLATINOM KOD PACOVA \\ Milica Pantić ${ }^{1 *}$ i Miloš Minić $2^{*}$ \\ ${ }^{1}$ Katedra za Fiziologiju, Fakultet medicinskih nauka, Univerzitet u Kragujevcu, Kragujevac, Srbija \\ ${ }^{2}$ Katedra za Anatomiju, Fakultet medicinskih nauka, Univerzitet u Kragujevcu, Kragujevac, Srbija \\ "Milica Pantić i Milos Minić su učestvovali podjednako (50\% svako) u izradi ovog rada, pa se oboje mogu smatrati prvim autorom
}

Received / Primljen: 13. 10. 2017.

Accepted / Prihvaćen: 16. 10. 2017.

\begin{abstract}
The aim of this study was to evaluate the potential beneficial effect of $N$-acetylcysteine (NAC) on cisplatin-induced alterations in anxiety levels in rats, by means of parameters of the exploratory activity obtained in the elevated plus maze (EPM) test. Animals were divided into four groups: control group, cisplatin group $(7.5 \mathrm{mg} / \mathrm{kg} /$ weekly of cisplatin), $\mathrm{N}$-acetylcysteine group (500 $\mathrm{mg} / \mathrm{kg} /$ weekly of NAC), and cisplatin plus $N$-acetylcysteine group $(7.5 \mathrm{mg} / \mathrm{kg} /$ weekly of cisplatin, and $500 \mathrm{mg} / \mathrm{kg} /$ weekly of NAC). After two weeks of treatment, exploratory activity (estimated by means of the number of rearings, head-dippings and the number of total exploratory activity episodes) was significantly reduced in cisplatin group comparing to control values. Although NAC induced no alterations in exploratory activity when applied alone, simultaneous administration with cisplatin resulted in significant attenuation of cisplatin-induced decline in exploratory activity. The exploratory activity gradually decreased in time-dependent manner during five minutes of EPM test in all groups. The results of this study confirmed clear beneficial effect of NAC supplementation against cisplatin-induced neurotoxicity in rats. Antioxidative properties of NAC were manifested through restoration of exploratory activity, confirming that NAC administration can attenuate anxiogenic effect of cisplatin therapy. Those results could recommend NAC supplementation as a potential protection against cisplatin-induced neurotoxicity.
\end{abstract}

Keywords: exploratory activity, cisplatin, $N$-acetylcysteine, neurotoxicity, rat

\section{SAŽETAK}

Cilj ovog istraživanja je bio ispitivanje potencijalno korisnog efekta N-acetilcisteina (NAC) na promene nivoa anksioznosti izazvane primenom cisplatine kod pacova, kroz parametre eksplorativne aktivnosti u uzdignutom krstastom lavirintu. Životinje su bile podeljene u četiri grupe: kontrolna grupa, cisplatina grupa (7.5 mg/kg/nedeljno cisplatine), $\mathrm{N}$ acetilcistein grupa $(500 \mathrm{mg} / \mathrm{kg} /$ nedeljno NAC-a) i kombinovana grupa $(7.5 \mathrm{mg} / \mathrm{kg} /$ nedeljno of cisplatin $i 500 \mathrm{mg} / \mathrm{kg} / \mathrm{ne}$ deljno NAC-a). Nakon dvonedeljnog tretmana, eksplorativna aktivnost (ispitivana kroz broj uspravljanja, naginjanja i broj epizoda ukupne eksplorativne aktivnosti) u cisplatina grupi je bila značajno smanjena u poređenju sa kontrolnim vrednostima. Iako samostalna primena NAC-a nije izazvala promene eksplorativne aktivnosti, simultana primena sa cisplatinom je uzrokovala značajno ublažavanje smanjenja eksplorativne aktivnosti izazvanog cisplatinom. Eksplorativna aktivnost se postepeno smanjivala u funkciji vremena u svim grupama tokom petominutnog izvođenja testa uzdignutog krstastog lavirinta. Rezultati ove studiji jasno potvrduju da suplementacija NAC-om može biti korisna kod neurotoksičnosti izazvane cisplatinom kod pacova. Antioksidantna svojstva NAC-a su se ispoljavala kao poboljšanje eksplorativne aktivnosti, što je potvrdilo da primena NAC-a može umanjiti anksiogeni efekat terapije cisplatinom. Ovi rezultati ukazuju da suplementacija NAC-om može biti potencijalna zaštita od neurotoksičnosti izazvane cisplatinom.

Ključne reči: ekplorativna aktivnost, cisplatina, $\mathrm{N}$-acetilcistein, neurotoksičnost, pacov

\section{ABBREVIATIONS}

NAC - N-acetylcysteine EPM - elevated plus maze
TEA - total exploratory activity

ROS - reactive oxygen species DOI: 10.1515SJECR-2017-0053
Corresponding author: Milica Pantic Department of Physiology; Faculty of Medical Sciences; University of Kragujevac, Svetozara Markovica 69 34000 Kragujevac; Serbia; 


\section{INTRODUCTION}

Cisplatin is anticancer drug which is widely used in the therapy of various types of malignancies. More than 40 years used as primary drug in the treatment of ovarian and testicular cancer, cisplatin also has been shown very effective in the treatment of other tumors, such as sarcoma, microcellular lung cancer, lymphoma, urinary bladder cancer, and cervical cancer. Great antitumor potential of cisplatin is based on its ability to form complexes with water molecules, replacing chlorine with water (aqua complexes), incorporating in DNA molecule and activating apoptosis (1).

Although it is considered as highly effective in treating tumors, cisplatin therapy is usually associated with various adverse effects such as: nephrotoxicity (2), hepatotoxicity (3), cardiotoxicity (4), hematotoxicity (5), nausea and vomiting (6), as well as neurotoxicity (7). In humans, neurotoxicity is usually manifested by peripheral nerves dysfunction and sensory disorders, seizures, reduced cognitive abilities and various mood disorders $(8,9)$. Studies performed on animal experimental models confirmed cisplatin-induced neurotoxicity by means of motor impairment (10), decline of cognitive functions (11), mood disorders (12) and alterations in nociception (13).

Adverse effects of cisplatin therapy are confirmed to be associated with increased oxidative damage (14). It has been reported that cisplatin treatment leads to enhanced free radicals production (15), reduced activity of antioxidant enzymes (16) and declined concentration of tissue glutathione (17) in various tissues. Since many adverse effects of cisplatin therapy seem to be accompanied with alterations in redox status, numerous antioxidants have been applied as supplementation during cisplatin therapy in order to diminish its toxicities. Among others, it has been reported that administration of vitamin $C(18)$, vitamin E (19), selenium (20), ginger (21), and/or ellagic acid (22) can decrease the severity of cisplatin adverse effects. Although neurotoxicity is not considered as one of the most frequent side effect of cisplatin, antioxidant supplementation showed beneficial effects by means of reduction in severity of cisplatin-induced neuronal damage. It has been reported that cisplatin-induced neurotoxicity may be attenuated by numerous antioxidants, such as: ethoxyguin (23), Echinophora cinerea (24), and flavaglines (25).

Numerous papers reported increased anxiety levels obtained in an adequate behavioral tests in various species following cisplatin treatment $(26,27)$. Since exploratory activity is considered as reliable indicator for evaluation of the anxiogenic action (28), the aim of this study was to evaluate the potential beneficial effect of $\mathrm{N}$ acetylcysteine (NAC, sulfur containing amino acid with antioxidant properties) on cisplatin-induced alterations in anxiety levels in rats, by means of parameters of the exploratory activity obtained in the elevated plus maze (EPM) test.

\section{MATERIAL AND METHODS}

Three months old male Wistar albino rats (weighting between 250-300 g, n=32) were used in this study. Animals were housed in groups of 3-4 per (polycarbonate) cage, under controlled environmental conditions of temperature $\left(23 \pm 1{ }^{\circ} \mathrm{C}\right)$ and light $(12 / 12 \mathrm{~h}$ light/dark cycle). Rats had ad libitum access to food and water. Animals were divided into four groups (8 animals in each group): control group, cisplatin group, $\mathrm{N}$-acetylcysteine (NAC) group, cisplatin plus $\mathrm{N}$ acetylcysteine group (cisplatin+NAC, i.e. combined group).

Cisplatin group received cisplatin (Bristol-Myers Squibb Co., USA, $7.5 \mathrm{mg} / \mathrm{kg} /$ weekly, intraperitoneally), while the rats from NAC group received NAC (SigmaAldrich, Germany, $500 \mathrm{mg} / \mathrm{kg} /$ weekly, intraperitoneally). Combined group was administered with cisplatin $(7.5 \mathrm{mg} /$ $\mathrm{kg} /$ weekly, intraperitoneally) and NAC (500 mg/kg/weekly, intraperitoneally). Control group received saline (intraperitoneally, approximately in the same volume as experimental groups). All protocols lasted for two weeks.

Two days after the protocols were finished, the rats were placed in a testing room for 1-2 $\mathrm{h}$ to accommodate before behavioral testing in EPM. During the behavioral testing, the maze was cleaned following the trial for each animal in order to remove possible interfering scents.

Apparatus used for testing was made of black wood, and consisted of two opposite open $(50 \times 20 \mathrm{~cm})$ and two opposite enclosed arms (50 x $20 \times 30 \mathrm{~cm})$, extended horizontally at $90^{\circ}$ from the central area $(20 \times 20 \mathrm{~cm})$. EPM was elevated $100 \mathrm{~cm}$ from the floor. Each animal was placed in the centre of the EPM facing one of the open arms. The tests lasted five minutes. The testing was recorded by digital video camera, placed approximately $2.5 \mathrm{~m}$ above the elevated plus maze. Video files were analyzed and the following parameters were estimated: the number of rearings, the number of head-dippings and then the total exploratory activity (TEA) was calculated according to previously described procedure (29). Also, we evaluated the exploratory activity in EPM test in time-dependent manner i.e. by analyzing the parameters mentioned above in successive periods during the whole test (5 minute), and expressed the values for applied parameters in each consecutive (one minute) sequences.

\section{Statistical analysis}

The data were expressed as the means \pm S.E.M. Parameters obtained in EPM test were initially submitted to Levene's test for homogeneity of variance and to Shapiro-Wilk test of normality. Comparisons between groups were performed using One-way ANOVA, followed by Fisher's least significant difference (LSD) multiple comparisons test. Comparisons within the groups (for TEA) were performed using unpaired Student t-test. Significance was determined at $\mathrm{p}<0.05$. Statistically analysis was performed with SPSS version 20.0 statistical package (IBM SPSS Statistics 20). 
All research procedures were carried out in accordance with European Directive for welfare of laboratory animals $\mathrm{N}^{\circ}$ 86/609/EEC and principles of Good Laboratory Practice (GLP), approved by Ethical Committee of the Faculty of Medical Sciences, University of Kragujevac, Serbia.

\section{RESULTS}

As shown in Figure 1, applied protocols significantly altered the number of rearings in $E P M$ test $(\mathrm{df}=3, \mathrm{~F}=4.135$, $6.936,16.880,4.143$ and 0.768 for five consecutive min- utes, respectively). Cisplatin administration significantly decreased the number of rearings compared to the control group (statistically significant during the first four minutes of the test, $p<0.01$ ). Independent application of NAC did not alter the number of rearings comparing to the control group maintaining the values significantly above cisplatin treated animals (also, statistically significant during the first four minutes of the test, $\mathrm{p}<0.01$ ). On the other hand, simultaneous administration of NAC during cisplatin treatment resulted in increased number of rearings comparing to cisplatin group (statistically significant in the $2^{\text {nd }}$ and $3^{\text {rd }}$ minutes, $\left.\mathrm{p}<0.05\right)$.
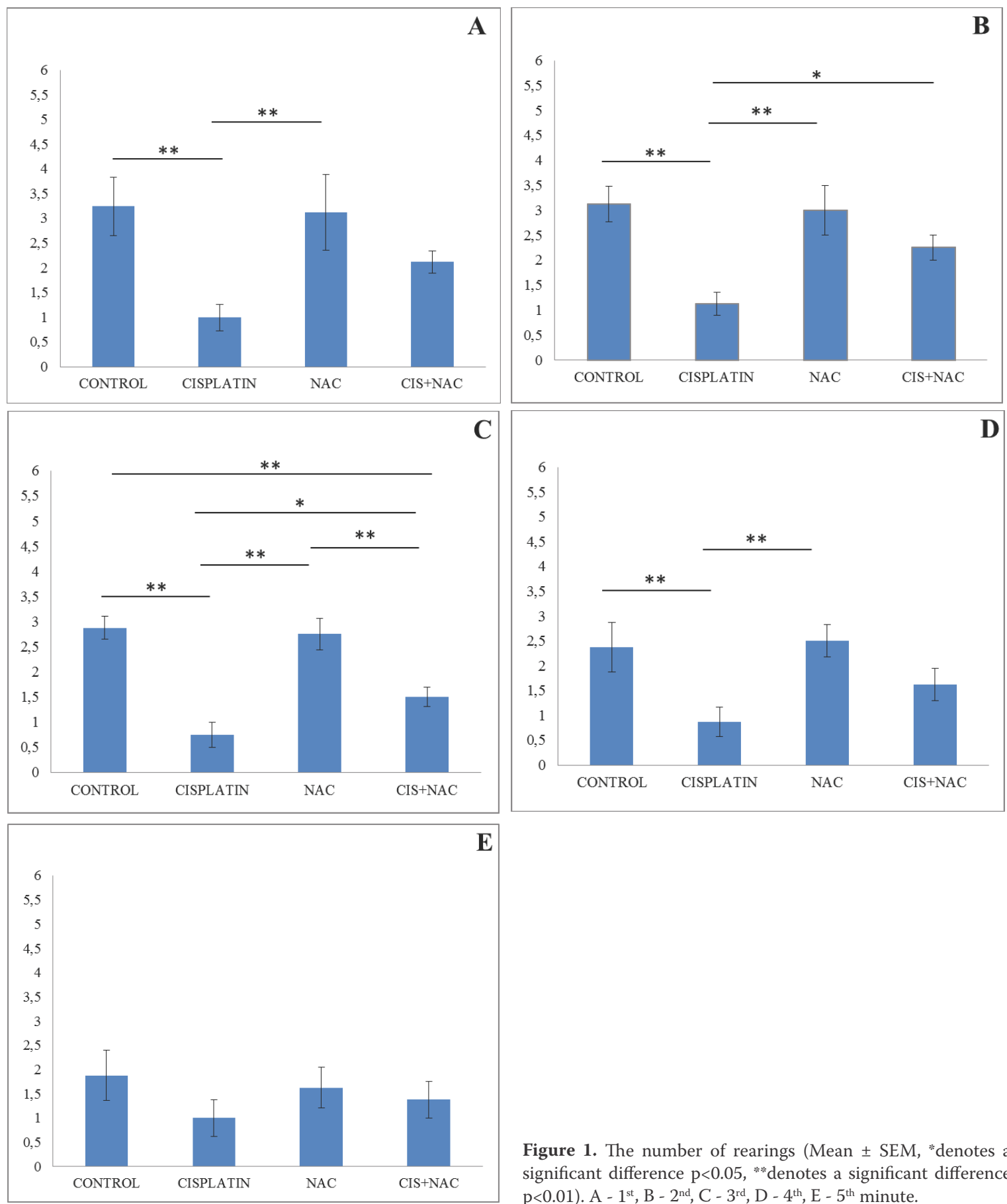

Figure 1. The number of rearings (Mean \pm SEM, "denotes significant difference $\mathrm{p}<0.05$, **denotes a significant difference $\mathrm{p}<0.01) . \mathrm{A}-1^{\text {st }}, \mathrm{B}-2^{\text {nd }}, \mathrm{C}-3^{\text {rd }}, \mathrm{D}-4^{\text {th }}, \mathrm{E}-5^{\text {th }}$ minute. 

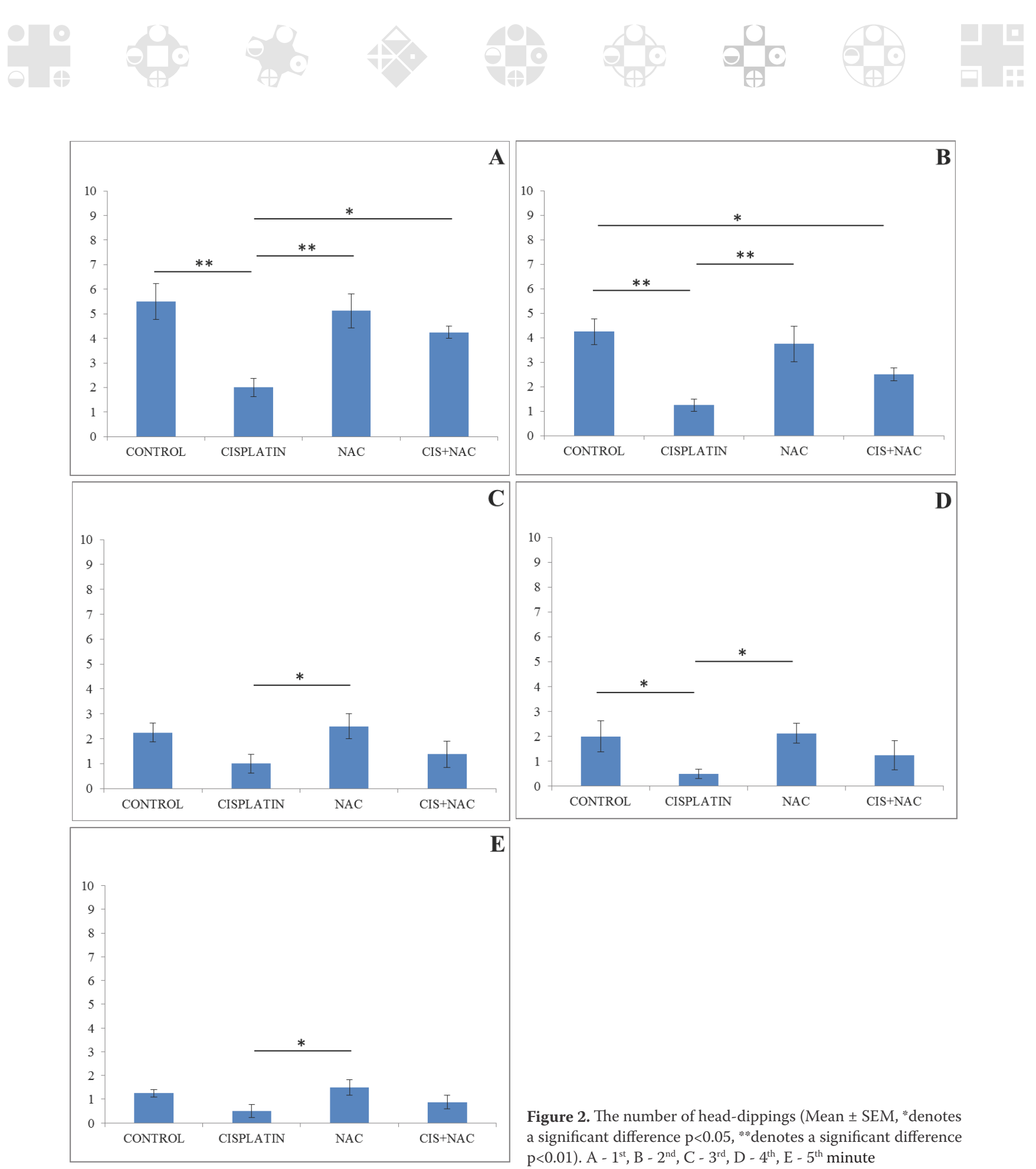

Figure 2. The number of head-dippings (Mean \pm SEM, "denotes a significant difference $\mathrm{p}<0.05, *$ denotes a significant difference $\mathrm{p}<0.01) . \mathrm{A}-1^{\text {st }}, \mathrm{B}-2^{\text {nd }}, \mathrm{C}-3^{\text {rd }}, \mathrm{D}-4^{\text {th }}, \mathrm{E}-5^{\text {th }}$ minute

Analyzing the exploratory activity in open arms of EPM, significant alterations in the number of head-dippings was induced by different protocols $(\mathrm{df}=3, \mathrm{~F}=8.066,7.711,2.488$, 2.422 and 2.618 for five consecutive minutes, respectively). It was noticed that cisplatin treatment resulted in significant decrease in the number of head-dippings (statistically significant in the $1^{\text {st }}$ and $2^{\text {nd }}$ minute, as well as in the $4^{\text {th }}$ minute, $\mathrm{p}<0.01$ and $\mathrm{p}<0.05$, respectively). As for the number of rearings, when applied alone, NAC treatment did not affected the number of head-dippings compared to control group, and the values were also significantly higher when compared to cisplatin group for the whole duration of the test (first two minutes, $\mathrm{p}<0.01,3^{\text {rd }}$ to $5^{\text {th }}$ minute $\mathrm{p}<0.05$ ). The number of head-dippings observed in the combined

group (Figure 2) was higher comparing to the cisplatin group (significantly only for the $1^{\text {st }}$ minute, $\mathrm{p}<0.05$ ), maintaining lower values when compared to control group (significantly only for the $2^{\text {nd }}$ minute, $\mathrm{p}<0.05$ ).

Applied protocols significantly altered TEA observed in EPM test $(\mathrm{df}=3, \mathrm{~F}=17.495,21.608,9.399,8.675$ and 1.829 for five consecutive minutes, respectively). As shown in Figure 3, the total exploratory activity was diminished in cisplatin group (statistically significant during the first four minutes of the test, $\mathrm{p}<0.01)$ comparing to control. When applied alone, NAC did not produce significant alterations in TEA comparing to the control group, and the values were also above the observed in cisplatin group (statistically significant in $1^{\text {st }}, 2^{\text {nd }}$ and $4^{\text {th }}$ minute, $\left.\mathrm{p}<0.01\right)$. Simul- 

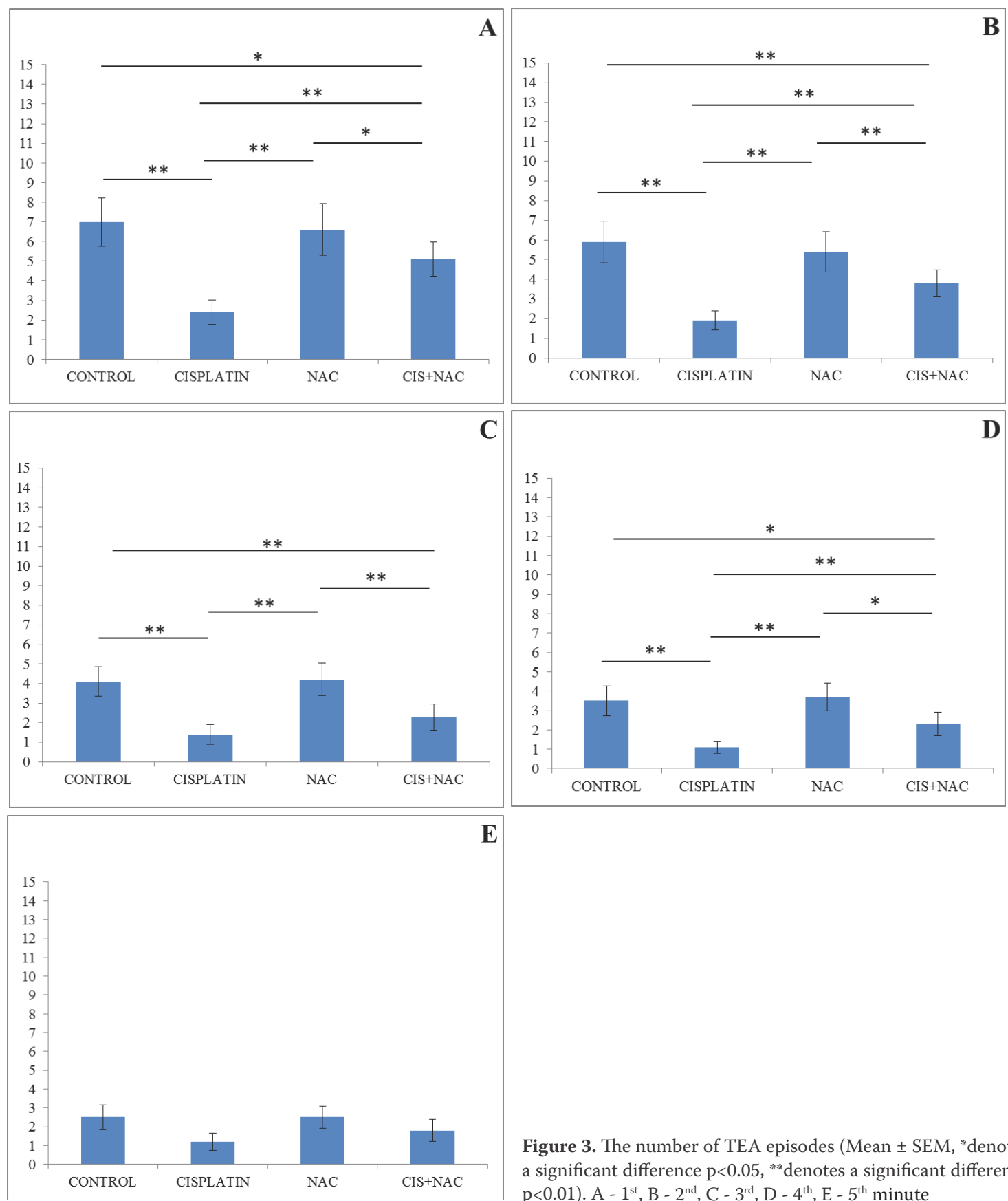

taneous administration NAC and cisplatin resulted in significant increase in TEA when compared to cisplatin group (statistically significant in $1^{\text {st }}, 2^{\text {nd }}$ and $4^{\text {th }}$ minute, $\mathrm{p}<0.01$ ), but the values remained significantly lower comparing to the control (statistically significant during the first four minutes of the test, $\mathrm{p}<0.01$ ).

Analyzing the time distribution of exploratory activity observed in EPM test (Figure 4), it is obvious that TEA progressively decline during the test. The stepwise attenuation of exploratory activity was observed in all tested groups. Since TEA gradually decreased, significant decline between two consecutive minutes was rarely observed: between $2^{\text {nd }}$ and $3^{\text {rd }}$ minute in control group $(\mathrm{p}<0.01)$, between $4^{\text {th }}$ and $5^{\text {th }}$ minute in NAC group $(\mathrm{p}<0.05)$, as well between $1^{\text {st }}$ and

Figure 3. The number of TEA episodes (Mean \pm SEM, "denotes a significant difference $\mathrm{p}<0.05$, ** denotes a significant difference $\mathrm{p}<0.01) . \mathrm{A}-1^{\text {st }}, \mathrm{B}-2^{\text {nd }}, \mathrm{C}-3^{\text {rd }}, \mathrm{D}-4^{\text {th }}, \mathrm{E}-5^{\text {th }}$ minute

$2^{\text {nd }}(\mathrm{p}<0.01)$, and $2^{\text {nd }}$ and $3^{\text {rd }}$ minute in combined group $(\mathrm{p}<0.05)$. Although TEA also progressively decreased following cisplatin administration, there was no significant decrease in time-dependent manner in cisplatin group.

\section{DISCUSSION}

Rising incidence of malignant diseases resulted in increased use of chemotherapeutic drugs, including cisplatin. Such therapeutic approach to malignancies often interferes with the course of treatment, so it is important to evaluate adverse effects of chemotherapy. Neurotoxicity is one of the many adverse effects of cisplatin therapy. In order to reduce 


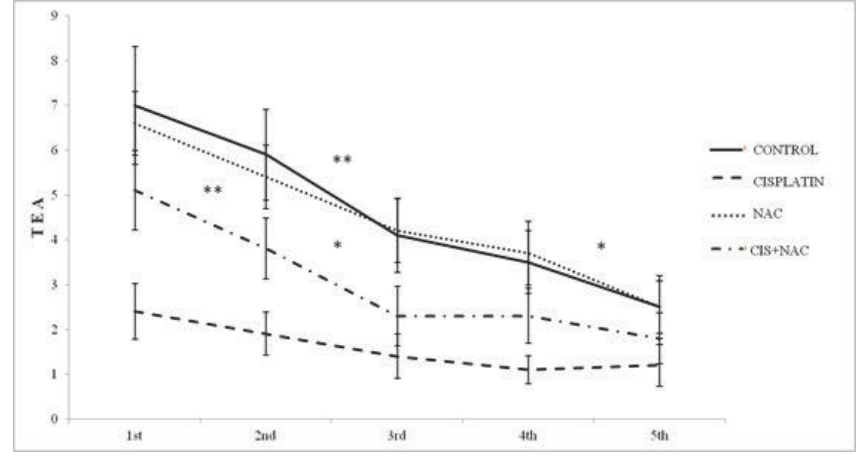

Figure 4. The time distribution of exploratory activity (Mean \pm SEM, *denotes a significant difference $\mathrm{p}<0.05,{ }^{* *}$ denotes a significant difference $\mathrm{p}<0.01$ )

the effects of cisplatin-induced neurotoxicity, it seems reasonable to investigate the possible underlying mechanisms of that specific side effect of cisplatin. It is well known that numerous metals of high atomic number (30), including platinum (31), lead to increased oxidative damage in various organic systems (32). Therefore, potential attenuation of oxidative damage that can improve clinical appearance during cisplatin treatment may be of substantial clinical relevance. According to the literature data, the dose of cisplatin applied in this study was sufficient to increase the platinum levels in serum and various tissues in clinical trials, as well as in animal experimental models. Consequently, this dose may also be considered as an adequate for investigation of cisplatininduced neurotoxicity (33).

Exploratory activity has been reported as a good parameter for evaluation of anxiety state level, in such a manner that decreased exploratory activity may be considered as indicator of increased anxiety (34). Cisplatin treatment resulted in significant reduction in exploratory activity in the EPM test by means of all estimated parameters. This finding is consistent with the results of another study (35) which also observed the development of anxiety-like behavior in cisplatin-treated rats in the EPM test. The results of our study (as shown in Figure 4) also showed that under control conditions animals demonstrate the highest level of exploratory activity at the very beginning of the test. The exploratory activity decreases during the testing, but without statistical significance. The observed reduction in exploratory activity may be explained by the fact that the animals adapt to the new environment over time. Such regularity was observed in all groups of animals. Gradual decline in exploratory activity was observed throughout the whole test, except for cisplatin group, by the end of the test $\left(4^{\text {th }}\right.$ and $5^{\text {th }}$ minute). Although NAC, as shown in the Figure1-3, did not lead to changes in exploratory activity compared to the control group when applied alone, combined application of NAC and cisplatin resulted in significant mitigation of cisplatin-induced reduction in exploratory activity. The results of this study showed the beneficial effect of NAC by means of reduced oxidative damage that consequently attenuated anxiogenic effect of cisplatin and restored exploratory activity almost to control values. Observed neuroprotective effect of NAC may be achieved as the result of reduced free radicals production (36), increased activity of antioxidant enzymes
(37) and/or tissue glutathione (38). A similar beneficial effect of an antioxidant supplementation on cisplatin-induced neurotoxicity (manifested by means of behavioral manifestetions) was observed for various nutritiens, such as walnuts. Walnuts contain potentially neuroprotective substances with anti-inflammatory and antioxidant properties (vitamin E, folate, melatonin, flavonoids and numerous polyphenolics) that were able to diminish cisplatin-induced neurotoxicity in rats (39). It is worth to notice that NAC administration also showed the beneficial effects by means of amelioration of cisplatin-induced cardiotoxicity in rats (33). The observed cardioprotective effect of NAC supplementation during cisplatin administration was accompanied with attenuation of oxidative damage induced by cisplatin administration. Antioxidant role of NAC in cisplatin-induced cardiotoxicity was achieved by means of decreased ROS production, with no alterations in tissue glutathione levels (33).

In conclusion, the results of this study confirmed clear beneficial effect of NAC supplementation against cisplatin-induced neurotoxicity in rats. Antioxidative properties of NAC were manifested through restoration of exploratory activity, confirming that NAC administration can attenuate anxiogenic effect of cisplatin therapy. Those results could recommend NAC supplementation as a potential protection against cisplatin-induced neurotoxicity.

\section{ACKNOWLEDGEMENTS}

This work was supported by Faculty of Medical Sciences (JP 01/13), University of Kragujevac, Serbia.

\section{REFERENCES}

1. Bednarski PJ, Korpis K, Westendorf AF, Perfahl S, Grünert R. Effects of light-activated diazido-PtIV complexes on cancer cells in vitro. Philos Trans A Math Phys Eng Sci. 2013;17:371.

2. Pabla N, Dong Z. Cisplatin nephrotoxicity: mechanisms and renoprotective strategies. Kidney Int. 2008;73(9):994-1007.

3. Waseem M, Bhardwaj M, Tabassum H, Raisuddin S, Parvez S. Cisplatin hepatotoxicity mediated by mitochondrial stress. Drug Chem Toxicol. 2015;38(4):452-9.

4. Oun R, Rowan E. Cisplatin induced arrhythmia; electrolyte imbalance or disturbance of the SA node? Eur J Pharmacol. 2017;811:125-8.

5. Karale S, Kamath JV. Effect of daidzein on cisplatininduced hematotoxicity and hepatotoxicity in experimental rats. Indian J Pharmacol. 2017;49(1):49-54.

6. Navari RM, Quin R, Ruddy KJ, Liu H, Powel SF, Bajaj M, Dietrich L, Biggs D, Lafky JM, Loprinzi CL. Olazapine for the prevention chemotherapy-induced nausea and vomiting. N Engl J Med. 2016;375(2):134-42.

7. Kanat O, Ertas H, Caner B. Platinum-induced neurotoxicity: A review of possible mechanisms. World J Clin Oncol. 2017;8(4):329-35. 
8. Krarup-Hansen A, Fugleholm K, Helweg-Larsen S, Hauge EN, Schmalbruch H, Trojaborg W, Krarup C. Examination of distal involvement in cisplatin-induced neuropathy in man. An electrophysiological and histological study with particular reference to touch receptor function. Brain. 1993;116 (5):1017-41.

9. Matsuoka A, Mitsuma A, Maeda O, Kajiyama H, Kiyoi H, Kodera Y, Nagino M, Goto H, Ando Y. Quantitative assessment of chemotherapy-induced peripheral neurotoxicity using a point-of-care nerve conduction device. Cancer Sci. 2016;107(10):1453-7.

10. Golchin L, Shabani M, Harandi S, Razavinasab M. Pistachio supplementation attenuates motor and cognition impairments induced by cisplatin or vincristine in rats. Adv Biomed Res. 2015;4:92.

11. Lomeli N, Di K, Czerniawski J, Guzowski JF, Bota DA. Cisplatin-induced mitochondrial dysfunction is associated with impaired cognitive function in rats. Free Radic Biol Med. 2017;102:274-86.

12. Abdelkader NF, Saad MA, Abdelsalam RM. Neuroprotective effect of nebivolol against cisplatin-associated depressive-like behavior in rats. J Neurochem. 2017;141(3):449-60.

13. Lee KH, Rhee KH. Anti-nociceptive effect of Agrimonia eupatoria exstract on a cisplatin-induced neurophatic model. Afr J Tradit Complement Altern Med. 2016;13(5):139-44.

14. Santos NA, Catão CS, Martins NM, Curti C, Bianchi ML, Santos AC. Cisplatin-induced nephrotoxicity is associated with oxidative stress, redox state unbalance, impairment of energetic metabolism and apoptosis in rat kidney mitochondria. Arch Toxicol. 2007;81(7):495-504.

15. Yao X, Panichpisal K, Kurtzman N, Nugent K. Cisplatin nephrotoxicity: a review. Am J Med Sci. 2007;334(2):115-24.

16. Nishikawa M, Nagatomi H, Nishijima M, Ohira G, Chang BJ, Sato E, Inoue M. Targeting superoxide dismutase to renal proximal tubule cells inhibits nephrotoxicity of cisplatin and increases the survival of cancer-bearing mice. Cancer Lett. 2001;171(2):133-8.

17. Zheng ZG, Xu H, Suo SS, Xu XL, Ni MW, Gu LH, Chen W, Wang LY, Zhao Y, Tian B, Hua YJ. The essential role of $\mathrm{H} 19$ contributing to cisplatin resistance by regulating glutathione metabolism in high-grade serous ovarian cancer. Sci Rep.2016;6:26093.

18. Guindon J, Deng L, Fan B, Wager-Miller J, Hohmann AG. Optimization of a cisplatin model of chemotherapy-induced peripheral neuropathy in mice: use of vitamin $\mathrm{C}$ and sodium bicarbonate pretreatments to reduce nephrotoxicity and improve animal health status. Mol Pain. 2014;10:56.

19. Villani V, Zucchella C, Cristalli G, Galiè E, Bianco F, Giannarelli D, Carpano S, Spriano G, Pace A. Vitamin E neuroprotection against cisplatin ototoxicity: Preliminary results from a randomized, placebo-controlled trial. Head Neck. 2016;38(1):2118-21.
20. Doğan S, Yazici H, Yalçinkaya E, Erdoğdu HI, Tokgöz SA, Sarici F, Namuslu M, Sarikaya Y. Protective Effect of Selenium Against Cisplatin-Induced Ototoxicity in an Experiemental Model. J Craniofac Surg. 2016;27(7):610-4.

21. Ali DA, Abdeen AM, Ismail MF, Mostafa MA. Histological, ultrastructural and immunohistochemical studies on the protective effect of ginger extract against cisplatin-induced nephrotoxicity in male rats. Toxicol Ind Health. 2015;31(10):869-80.

22. Yüce A, Ateșşahin A, Ceribaşi AO, Aksakal M. Ellagic acid prevents cisplatin-induced oxidative stress in liver and heart tissue of rats. Basic Clin Pharmacol Toxicol. 2007;101(5):345-9.

23.Zhu J, Carozzi VA, Reed N, Mi R, Marmiroli P, Cavaletti G, Hoke A. Ethoxyquin provides neuroprotection against cisplatin-induced neurotoxicity. Sci Rep. 2016;6:28861.

24. Shokoohinia Y, Khajouei S, Ahmadi F, Ghiasvand N, Hosseinzadeh L. Protective effect of bioactive compounds from Echinophora cinerea against cisplatininduced oxidative stress and apoptosis in the PC12 cell line. Iran J Basic Med Sci. 2017;20(4):438-45.

25. Ribeiro N, Thuaud F, Bernard Y, Gaiddon C, Cresteil T, Hild A, Hirsch EC, Michel PP, Nebigil CG, Désaubry L. Flavaglines as potent anticancer and cytoprotective agents. J Med Chem. 2012;55(22):10064-73.

26. Wiechno P, Demkow T, Kubiak K, Sadowska M, Kamińska J. The quality of life and hormonal disturbances in testicular cancer survivors in Cisplatin era. Eur Urol. 2007;52(5):1448-54.

27. Eberhard J, Ståhl O, Cohn-Cedermark G, CavallinStåhl E, Giwercman Y, Rastkhani H, Rylander L, Eberhard-Gran M, Kvist U, Giwercman A. Emotional disorders in testicular cancer survivors in relation to hypogonadism, androgen receptor polymorphism and treatment modality. J Affect Disord. 2010;122(3):260-6.

28. Pellow S, Chopin P, File SE, Briley M. Validation of open:closed arm entries in an elevated plus-maze as a measure of anxiety in the rat. J Neurosci Methods. 1985;14(3):149-67.

29. Selakovic D, Joksimovic J, Obradovic D, Milovanovic D, Djuric M, Rosic G. The adverse effects of exercise and supraphysiological dose of testosterone-enanthate (TE) on exploratory activity in elevated plus maze (EPM) test - indications for using total exploratory activity (TEA) as a new parameter for ex. Neuro Endocrinol Lett. 2016;37(5):383-8.

30. Kawanishi S, Yamamoto K. Mechanism of site-specific DNA damage induced by methylhydralazines in the presence of cooper (II) or manganese (III). Biochemistry. 1991;30(12):3069-75.

31. Yousef MI, Saad AA, El-Shennawy LK. Protective effect of grape seed proanthocyanidin extract against oxidative stress induced by cisplatin in rats. Food Chem Toxicol. 2009;47(6):1176-83. 
32. Townsend DM, Tew KD, He L, King JB, Hanigan $\mathrm{MH}$. Role of glutathione S-transferase Pi in cisplatin-induced nephrotoxicity. Biomed Pharmacother. 2009;63(2):79-85.

33. Rosic G, Selakovic D, Joksimovic J, Srejovic I, Zivkovic V, Tatalovic N, Orescanin-Dusic Z, Mitrovic S, Ilic M, Jakovljevic V. The effects of $\mathrm{N}$-acetylcysteine on cisplatin-induced changes of cardiodynamic parameters within coronary autoregulation range in isolated rat hearts. Toxicol Lett. 2016;242:34-46.

34. Costa AA, Morato S, Roque AC, Tinos R. A computational model for exploratory activity of rats with different anxiety levels in elevated plus-maze. J Neurosci Methods. 2014;236:44-50.

35. Mu L, Wang J, Cao B, Jelfs B, Chan RH, Xu X, Hasan M, Zhang X, Li Y. Impairment of cognitive function by chemotherapy: association with the disruption of phase-locking and synchronization in anterior cingulate cortex. Mol Brain. 2015;8:32.

36. Wang W, Li D, Ding X, Zhao Q, Chen J, Tian K, Qiu Y, Lu L. N-Acetylcysteine protects inner ear hair cells and spiral ganglion neurons from manganese exposure by regulating ROS levels. Toxicol Lett. 2017; 279:77-86.

37. Wang J, Zhu H, Liu X, Liu Z. N-acetylcysteine protects against cadmium-induced oxidative stress in rat hepatocytes. J Vet Sci. 2014;15(4):485-93.

38. Ortiz MS, Forti MK, Suarez Martinez BE, Munoz GL, Husain K, Muniz HW. Effects of antioxidant N-acetylcysteine against paraquat-induced oxidative stress in vital tissues mice. Int J Sci Basic Appl Res. 2016;26(1):26-46.

39. Shabani M, Nazeri M, Parsania S, Razavinasab M, Zangiabadi N, Esmaeilpour K, Abareghi F. Walnut consumption protects rats against cisplatin-induced neurotoxicity. Neurotoxicology. 2012;33(5):1314-21. 